$1-1-1989$

\title{
State Taxation and the Supreme Court
}

Walter Hellerstein

University of Georgia School of Law, wallyh@uga.edu

D bepress

\section{Repository Citation}

Walter Hellerstein, State Taxation and the Supreme Court (1989),

Available at: https://digitalcommons.law.uga.edu/fac_artchop/488

This Article is brought to you for free and open access by the Faculty Scholarship at Digital Commons @ University of Georgia School of Law. It has been accepted for inclusion in Scholarly Works by an authorized administrator of Digital Commons @ University of Georgia School of Law. Please share how you have benefited from this access For more information, please contact tstriepe@uga.edu. 


\section{STATE TAXATION AND THE}

\section{SUPREME COURT}

The Supreme Court's outpouring of significant state tax decisions in recent years has elicited little more than a yawn from most constitutional scholars. The nation's preeminent law reviews, which once were filled with articles examiming the Court's state tax opinions, ${ }^{1}$ pay scant attention to them today. Leading constitutional law casebooks make only passing reference to state taxation. ${ }^{2}$ Indeed, the Court itself has expressed ennui over the prospect of adjudicating a seemingly endless stream of state tax controversies. ${ }^{3}$

The lack of academic interest in the Court's state tax jurisprudence may be attributable to several factors. Matters of greater cosmic significance-abortion, affirmative action, and capital punishment, to name a few-may have crowded state tax questions off scholarly

Walter Hellerstein is Professor of Law at the University of Georgia.

AurHor's NotE: I wish to thank Milner Ball, Robert Brussack, Paul Kurtz, and James Smith for their helpful comments on an earlier draft of this article.

'See, e.g., Bittker, The Taxation of Out-of-State Tangible Property, 56 Yale L.J. 640 (1947);

Dunham, Gross Receipts Taxes on Interstate Transactions, 47 Colum. L. Rev. 211 (1947); Lowndes, The Tax Decisions of the Supreme Corut, 1938 Term, 88 U. Pa. L. Rev. 1 (1939); Traynor, State Taxation and the Supreme Court, 1938 Term, 28 Calif. L. Rev. 1 (1939); Developments in the Law-Federal Limitiations on State Taxation of Interstate Business, 75 Harv. L. Rev. 953 (1962).

2See Stone, Seidman, Sunstein \& Tushnet, Constitutional Law 210-12, 262, 287-93 33637, 521-22 (1986); Gunther, Constitutional Law 331-34 (11th ed. 1985). In earlier editions, Professor Gunther devoted considerable attention to state taxation. See Gunther, Constitutional Law 684-765, 771-75 (8th ed. 1970).

${ }^{3}$ See, e.g., American Trucking Ass'ns, Inc. v. Scheiner, 483 U.S. 266, 268 (1987) ("[a]gain we are ${ }^{\prime}$ asked to decide whether state taxes applied to an interstate motor carrier run afoul of the commerce clause"'); Contaimer Corp. of America v. Franchise Tax Bd., 463 U.S. 159, 162 (1983) (" [ $[$ t]his is another appeal claiming that the application of a state taxing scheme violates the Due Process and Commerce Clauses of the Federal Constitution").

(C) 1990 by The University of Chieago. All rights reserved.

0-226-09571-1/90/1989-0007\$02.00 
agendas. The complex and technical rules that often inform state tax disputes may have led other scholars to embrace the view of a distinguished student of constitutional law: "pursuit of the intricacies of state taxation . . . would require more time and space than the undertaking warrants." 4 And the disrepute into which conventional doctrinal analysis has fallen in certain quarters may have induced still other scholars to avoid an area in which doctrinal concerns drive the judicial process and political and social considerations play a distinctly secondary role.

Whatever the reason, the fact remains that the Court's output in this domain has been extraordinary, and its opinions have had an enormous theoretical and practical impact. ${ }^{5}$ The Court's 1988 Term was no exception: it considered eleven state tax cases and handed down full-dress opinions in eight, ${ }^{6}$ confronting issues arising under the Commerce, Due Process, Equal Protection, and Supremacy Clauses, the First and Eleventh Amendments, and the intergovernmental and Indian immunity doctrines. The constitutional landscape in the state tax field deserves some re-mapping in light of the Court's recent decisions.

${ }^{4}$ Gunther, note 2 supra, at 332-33.

sSee Hellerstein, Is "Internal Consistency" Foolish?: Reflections on an Emerging Commerce Clause Restraint on State Taxation, 87 Mich. L. Rev. 138 (1988); Hellerstein, Commerce Clause Restraints on State Taxation: Purposeful Economic Protectionsm and Beyond, 85 Mich. L. Rev. 758 (1987); Hellerstein, Complementary Taxes as a Defense to Unconstitutional State Tax Discrimination, 39 Tax Law. 405 (1986); Hellerstein, State Income Taxation of Multijurisdictional Corporations, Part II: Reflections on ASARCO and Woolworth, 81 Mich. L. Rev. 157 (1982); Hellerstein, Constitutional Limitations on State Tax Exportation, $1982 \mathrm{Am}$. Bar Found. Res. J. 1; Hellerstein, State Income Taxation of Multijurisdictional Corporations: Reflections on Mobil, Exxon, and H.R. 5076, 79 Mich. L. Rev. 113 (1980); Hellerstein, State Taxation and the Supreme Court: Toward a More Umified Approach to Constitutional Adjudication?, 75 Mich. L. Rev. 1426(1977); Hellerstein, Michelin Tire Corp. v. Wages: Enhanced State Power to Tax Exports, 1976 Supreme Court Review 99; Hellerstcin, State Taxation and the Supreme Court, 1974 Term: Standard Pressed Steel and Colonial Pipeline, 62 Va. L. Rev. 149 (1976).

${ }^{6}$ Shell Oil Co. v. Iowa Dep't of Revenue, 109 S.Ct. 278(1988); Goldberg v. Sweet, 109 S.Ct. 582 (1989); Allegheny Pittsburgh Coal Co. v. County Comm'n, 109 S.Ct. 633 (1989); Texas Monthly Co. v. Bullock, 109 S.Ct. 890 (1989); Davis v. Michigan Dep't of Treasury, 109 S.Ct. 1500 (1989); Amerada Hess Corp. v. Director, Div. of Taxation, 109 S.Ct. 1617 (1989); Cotton Petroleum Corp. v. New Mexico, 109 S.Ct. 1698 (1989); California State Bd. of Equalization v. Sierra Summit, Inc., 109 S.Ct. 2228 (1989). The Court heard oral argument in two companion cases, involving the question whether taxpayers have a federal constitutional right to a refund of state taxes held to be unconstitutionally discriminatory under the Commerce Clause, McKesson Corp. v. Division of Alcoholic Beverages and Tobacco, cert. granted, 109 S.Ct. 389 (1988) and American Trucking Ass'ns, Inc. v. Smith, cert. granted, 109 S.Ct. 389 (1988), but subsequently set the cases for rcargument during its 1989 Term. 109 S.Ct. 3238 (1989). In a brief per curiam opinion, the Court held that a suit by Oklahoma against an Indian Tribe for failure to collect state excise taxes on cigarette sales and bingo receipts was improperly removed from state to federal court. Oklahoma Tax Comm'n v. Graham, 109 S.Ct. 1519(1989). 


\section{The Commerce Clause}

The Commerce Clause has long been the linchpin of the Court's state tax jurisprudence. Despite Justice Scalia's skepticism over the existence "of any clear theoretical underpinning for judicial 'enforcement' of the Commerce Clause," the Court's interpretation of the Commerce Clause remains the most significant constitutional restraint on state tax power-as it has been for more than a century. ${ }^{8}$ In its 1977 opinion in Complete Auto Transit, Inc. v. Brady, ${ }^{9}$ the Court sought to "clear up the tangled underbrush of past cases"10 by articulating a four-part test to govern the validity of state taxes under the Commerce Clause. A tax must be applied to an activity that has a substantial nexus with the state; it must be fairly apportioned to activities carried on by the taxpayer in the state; it must not discriminate against interstate commerce; and it must be fairly related to services provided by the state. In opinions subsequent to Complete Auto Transit, the Court has faithfully adhered to this four-part test, which it has characterized as a "consistent and rational method of inquiry" that looks to "the practical effects of a challenged tax" on interstate commerce. II

The Court reiterated its commitment to the analytical framework established in Complete Auto Transit in both of the Commerce Clause opimons it rendered during the 1988 Term. In Goldberg v. Sweet, ${ }^{12}$ involving a challenge to Illinois' telecommunications excise tax, the Court observed:13

This Court has frequently had occasion to consider whether state taxes violate the Commerce Clause. The wavering doctrinal lines of our pre-Complete Auto cases reflect the tension between two competing concepts: the view that interstate commerce enjoys a "free trade" immunity fron state taxation; and the view that businesses engaged in interstate commerce may be required to pay their own way. Complete Auto sought to resolve this tension

7Tyler Pipe Industries, Inc. v. Washington Dep't of Revenue, 483 U.S. 232, 260 (1983) (Scalia, J., concurring and dissenting).

${ }^{8}$ See generally Hellerstein, State Taxation of Interstate Business: Perspectives on Two Centuries of Constitutional Adjudication, 41 Tax Law. 37, 40-45 (1987).

9430 U.S. 274 (1977).

${ }^{10}$ Spector Motor Service, Inc. v. O'Connor, 340 U.S. 602, 612 (1951) (Clark, J., dissenting).

"Mobil Oil Corp. v. Commissioner of Taxes, 445 U.S. 425, 443 (1980).

I2109 S.Ct. 582 (1989).

${ }^{13} I d$. at $587-88$ (citations ounitted). 
by specifically rejecting the view that the States cannot tax interstate commerce, while at the same time placing limits on state taxation of interstate commerce. Since the Complete Auto decision we have applied its four-prong test on numerous occasions. We now apply it to the Illinois tax.

Similarly, in Amerada Hess Corp. v. Division, Director of Taxation, ${ }^{14}$ involving a challenge to New Jersey's denial of a state corporate income tax deduction for federal windfall profit taxes, the Court declared: ${ }^{15}$

In Complete Auto Transit, Inc. v. Brady, this Court sustained a state tax "against Commerce Clause challenge when the tax is applied to an activity with a substantial nexus with the taxing State, is fairly apportioned, does not discriminate against interstate commerce, and is fairly related to services provided by the taxing State." We repeatedly have applied this principle in subsequent cases, most recently this Term in Goldberg v. Sweet. Appellants do not dispute the soundness of the Complete Auto standard . . . . Rather they argue that the ... Tax ... fails each of the four prongs of the Complete Auto test.

The Court's ritualistic invocation of a verbal formula for adjudicating Commerce Clause challenges to state taxes cannot provide easy answers to hard questions. Nevertheless, in an area of the law in which hundreds of cases had left "much room for controversy and confusion and little in the way of precise guides to the States in the exercise of their indispensable power of taxation," 16 the Court's effort to analyze the issues in a "consistent and rational" 17 manner has helped to delineate the controlling constitutional principles governing state taxation of interstate commerce.

\section{A. NEXUS}

The nexus requirement reflects the fundamental notion that there must be "some definite link, some minimum connection between a state and the person, property, or transaction it seeks to tax."18 In recent years, the Court has been quite indulgent in finding the requi-

${ }^{14} 109$ S.Ct. 1617 (1989).

${ }^{15} 1 d$. at 1621 (citations omitted).

16Northwestern States Portland Cement Co. v. Minnesota, 358 U.S. 450,457 (1959).

${ }^{17}$ See note 11 supra.

${ }^{18}$ Miller Bros v. Maryland, 347 U.S. 340, 344-45 (1954). While Miller Brotbers was decided under the Due Process Clause, the nexus requirement has been incorporated into the Court's Commerce Clause doctrine. See text at note 15 supra. 
site nexus to justify the exercise of state tax power. The Court has sustained a state's power to impose a use tax on catalogs shipped from outside the state directly to the taxpayer's in-state customers. ${ }^{19} \mathrm{It}$ has also sustained a state's power to tax all the receipts derived by an outof-state supplier from sales to an in-state purchaser on the basis of the presence of the supplier's single resident employee..$^{20} \mathrm{And}$, while rejecting the notion that the "slightest presence" of an out-of-state vendor constitutes a sufficient nexus to require the vendor to collect use taxes, ${ }^{21}$ the Court has nevertheless sustained use tax collection liability on the basis of in-state activities that many would regard as insubstantial. ${ }^{22}$

The most hotly debated nexus issue in the state tax field today, on which more than a bilkion dollars of tax revenues ride, ${ }^{23}$ is whether the states may require an out-of-state mail-order vendor to collect use taxes on catalog sales. In 1967 the Court held in National Bellas Hess, Inc. v. Department of Revenue ${ }^{24}$ that a state lacks the constitutional power $^{25}$ to require an out-of-state mail order vendor, whose only contacts with the state are by mail or common carrier, to collect the state's use tax on goods sold and shipped to customers in the state. After chafing under the decision for the past two decades, the states now assert that subsequent developments have undermined the factual and legal premises underlying National Bellas Hess.

The states contend that the economic environment in which $\mathrm{Na}$ tional Bellas Hess was decided has changed dramatically. They point to the spectacular growth in the mail-order industry, now estimated

19D. H. Holmes Co. v. McNamara, 108 S.Ct. 1619 (1988).

20Standard Pressed Steel Co. v. Department of Revenue, 419 U.S. 560, 562 (1975).

${ }^{21}$ National Geographic Soc'y v. State Bd. of Equalization, 430 U.S. 551 (1977).

22See ibid. (magazine employed four in-state employees at two offices to solicit advertising unrelated to mail-order sales on which tax was imposed); Scripto, Inc. v. Carson, 362 U.S. 207 (1960) (company used ten in-state independent eontractors to make sales).

${ }^{23}$ U.S. Advisory Commission on Intergovernmental Relations, State and Local Taxation of Out-of-State Mail Order Sales 31 (1986).

24386 U.S. 753 (1967).

${ }^{25}$ The Court referred to both the Commerce and the Due Process Clauses in reaching its decision, but the decision was rooted in the Commerce Clause. See Interstate Sales Tax Collection Act of 1987 and the Equity in Interstate Competition Act of 1987: Hearings on H.R. 1242, H.R. 1891, and H.R. 3521 Before the Subcomm. on Monopolies and Commercial Law of the House Comm. on the Judiciary, 100th Cong., 2d Sess. 347-48 (1988) (testimony of Walter Hellerstein). The question whether the Court's decision was based on the Due Process Clause as well as the Commerce Clause may be significant with respect to the power of Congress to overrule National Bellas Hess, an option it is presently considering. Ibid. pasim. 
to generate sales of more than $\$ 50$ billion per year, ${ }^{26}$ as well as to striking changes in marketing techniques that permit mail-order sellers to reach consumers through toll-free (800) telephone numbers and computer terminals. They also assert that technological advances in communications, including automated accounting systems, should dispel the Court's concern voiced in National Bellas Hess that imposing a use tax collection obligation on a mail-order seller would create a "welter of complicated obligations to local jurisdictions"27that would frustrate the Commerce Clause purpose of ensuring "a national economy free from such unjustifiable local entanglements."28

The states also point to changes in the legal environment. They claim that since National Bellas Hess was decided, the Court has discredited the idea underlying the decision that physical presence in the state is a sine qua non of the state's authority to assert its coercive power over an out-of-state resident or business. They find support for their position in cases such as Burger King v. Rudzewicz, ${ }^{29}$ sustaining personal jurisdiction over nonresident defendants without physical presence in the state. "[I]t is an inescapable fact of modern cominercial life," the Court there observed, 30

that a substantial amount of business is transacted solely by mail and wire communications across state lines, thus obviating the need for physical presence within a State in which business is conducted. So long as a commercial actor's efforts are "purposefully directed" towards residents of another State, we have consistently rejected the notion that an absence of physical contacts can defeat personal jurisdiction there.

The Court's opinion in Goldberg v. Sweet is certain to fuel the debate over the continuing vitality of National Bellas Hess. In Goldberg, the Court addressed the question whether Illinois' Telecommumications Excise Tax Act ${ }^{31}$ violated the Commerce Clause. The tax was im-

\footnotetext{
${ }^{26}$ U.S. Advisory Commission on Intergovernmental Relations, note 23 supra, at 4 . The intermediate estimate for 1985 was $\$ 44.9$ billion, with industry estinates well in excess of $\$ 100$ billion. Id. at 3.

${ }^{27}$ National Bellas Hess, 386 U.S. at 759-60.

${ }^{28}$ Id. at 760 . See Hartman, Collection of the Use Tax on Out-of-State Mail-Order Sales, 39 Vand. L. Rev. 993, 1011-12 (1986).

29471 U.S. 462 (1985).

${ }^{30} I d$. at 476 . See also Keeton v. Hustler Magazine, Inc., 465 U.S. 770 (1984) (sustaining personal jurisdiction over out-of-state defendant based on circulation within the state of the defendant's magazines).

${ }^{31}$ III. Rev. Stat. ch. 120, 2001-2021 (1987).
} 
posed on the "act or privilege" of "originating" or "receiving" interstate telecommunications in the state at the rate of 5 percent of the gross charge for the telecommunications. ${ }^{32}$ The tax applied only to calls charged to an Illinois service address, ${ }^{33}$ which the Court understood to mean the address where the telephone equipment was located, ${ }^{34}$ regardless of where the telephone call charge was billed or paid. An identical 5 percent tax was also imposed on intrastate telecommunications by another section of the Act. To avoid multiple taxation of the call by more than one state, the Act provided a credit to any taxpayer upon proof that the taxpayer had paid a tax to another state on the same interstate telecommunication taxed by Illinois. ${ }^{35}$ The tax was collected by the retailer of the taxable telecommunication (i.e., the telecommunications provider) from the consunier whose service address was charged. 36

The parties agreed that Illinois had a substantial nexus with the interstate telecommunications taxed by the Act, ${ }^{37}$ so the Court was not conipelled to address the first prong of its Commerce Clause test. Nevertheless, in considering the question whether the Illinois levy threatened to expose the taxpayer to multiple taxation in violation of the Commerce Clause's fair apportionment requirement, ${ }^{38}$ the Court focused on the possibility that nore than one state would have the requisite nexus, and hence the requisite power, to impose a tax on the same telephone call that was subject to tax in Illinois.

In finding that the taxpayers had overstated the risk of multiple taxation, the Court expressed "doubt that States through which the telephone call's electronic signals merely pass have a sufficient nexus to tax that call." 99 The Court hikewise expressed "doubt that termi-

32Ill. Rev. Stat. ch. 120, 2004, § 4 (1987).

33Ill. Rev. Stat. ch. 120, 2002, \& 2(a), 2(b) (1987).

${ }^{34} 109$ S.Ct. at 586 n.6.

${ }^{35}$ Ill. Rev. Stat. ch. 120, 2004, 84 (1987).

36Ill. Rev. Stat. ch. 120, 2005, \& 5 (1987).

${ }^{37} 109$ S.Ct. at 588.

38This issue is considered more fully below. See text accompanying notes 59-74 infra.

39109 S.Ct. at 589. The Court cited United Air Lines, Inc. v. Mahin, 410 U.S. 623, 631 (1973) and Northwest Airlines, Inc. v. Minnesota 322 U.S. 292, 302-04 (1944) (Jackson, J., concurring) for the proposition that a state has no nexus to tax an airplane based solely on its flight over the state. The holding of neither case actually supports the proposition for which it is cited. In Mabin, the Court sustained a state's power to apply its fuel use tax to aviation fuel stored temporarily in the state prior to loading aboard aircraft for consumption in interstate flights. In Nortbrwest Airlines, the Court held that the state of an airline's incorporation, principal place of business, and major repair base could inpose a property tax on the entire value of 
nation of an interstate call, by itself, provides a substantial enough nexus for a State to tax a call." 40 For this proposition, the Court cited National Bellas Hess with the parenthetical comment that "receipt of mail provides insufficient nexus." 41 Hence the good news from Goldberg for out-of-state vendors is that the Court harbors serious reservations about the power of states to tax out-of-state firms who exploit a state's market solely through electronic media ${ }^{42}$ or the mail and that National Bellas Hess remains good law.

There is also bad news from Goldberg for out-of-state vendors, however. For the Court, in assessing the risk of multiple taxation arising from the Illinois taxing scheme, identified two states that do have sufficient nexus to tax a consumer's purchase of an interstate telephone call: a state like Illinois which taxes the origination or termination of an interstate telephone call charged to a service address within that state, and a state which taxes the origination or termination of an interstate telephone call billed or paid for within that state. ${ }^{43}$ While the Court's dicta thus suggest that neither the receipt of a telephone call-nor the receipt of mail by itself creates a taxable nexus under the Commerce Clause, the two events in combination do create such nexus. Otherwise the Court could not have declared that a state which taxes the termination of an interstate telephone call billed within the state would have nexus to tax such call. Under the Court's reasoning, only the out-of-state vendor which carefully structures its operations so as to communicate with its customers exclusively through electronic media or exclusively through the mails would retain Commerce Clause immunity from collecting the state's use tax. ${ }^{44}$

its fleet of planes without apportionment. The Court's dictum in Goldberg may cast a shadow over the holding of state tribunals that sales and use taxes may be imposed on the in-flight sale of liquor on flights that merely pass over the state, Republic Airlines, Inc. v. Department of Revenue, Wis. Tax Appeals Comm'n, May 4, 1989, reported in [Wis.] State Tax Rptr. (CCH) ף203-058, and that overflight time may be taken into account in apportioning an airline's aircraft to the state. Alaska Airlines, Inc. v. Department of Revenue, 307 Ore. 406, 769 P.2d 193 (1989).

${ }^{40} 109$ S.Ct. at 589-90.

41 Id. at 590 .

${ }^{42}$ This assumes that one ean draw a reasonable analogy between the requisite nexus for taxing an interstate service (the telecommunication) and the requisite nexus for requiring an out-of-state vendor to collect a tax on a transaction generated by that service.

${ }^{43} I d$. at 109.

${ }^{44}$ This assumes that the requisite nexus for taxing an interstate phone eall is substantially the same as the requisite nexus for requiring an interstate vendor to collect the tax on a sale generated by the phone call. See note 42 supra. Even on this assumption, however, it might be argued 
Though less tantalizing than its dicta in Goldberg, the Court's disposition of the nexus issue in Amerada Hess was not without significance. In Amerada Hess, most of the nation's major integrated oil companies attacked the constitutionality of New Jersey's denial of a deduction for federal windfall profit taxes from the state corporate income tax base. The windfall profit tax is an excise tax imposed on the "windfall profit" from the production of crude oil. ${ }^{45}$ Because the windfall profit tax is an expense attributable to the production of oil, and because the oil compames engaged in no oil production in New Jersey, they claimed that denying a deduction for an expense attributable to out-of-state production, while including income from that production in their apportionable tax base, ${ }^{46}$ was equivalent to imposing a tax on such out-of-state production. In so doing, New Jersey was allegedly imposing a tax on a transaction with which it lacked nexus.

The Court gave this argument less attention than it deserved. Seizing on the fact that the oil compamies were admittedly carrying on an integrated "uritary business" 47 in New Jersey, the Court ob-

that no nexus would be created under the typical telephone order that is filled by mail. The customer would ordinarily make a toll-free call that would be billed to the vendor's location. The Court gave no indieation that the mere origination of a telephone call by an im-state customer would provide nexus over the out-of-state vendor when the call was billed to the out-ofstate vendor. The fulfillment of the customer's order by mail would likewise fail to provide sufficent nexus under National Bellas Hess. The Court's position, however, that a state has nexus 'to tax the origination of an interstate telephone call billed within the state, $109 \mathrm{~S}$.Ct. at 590 , undercuts this argument, unless there is some basis for not considering the contact with the out-of-state vendor resulting from the origination of the telephone call in conjunction with the resulting mail-order sale for purposes of establishing nexus over the out-of-state vendor. The claim that the mail-order sale must be viewed in isolation from other contacts the out-ofstate vendor has with the taxing state for purposes of establishing the out-of-state vendor's obligation to collect use taxes eannot be sustained in light of National Geographic Society v. State Board of Equalization, 430 U.S. 551 (1977) (nexus over out-of-state vendor created by in-state activities unrelated to mail-order sales).

4526 U.S.C. $\$ 4986-4998$ (1982). The levy is imposed on taxable crude oil removed from the premises after February 29, 1980. Broadly speaking, the "windfall profit" associated with any particular barrel of oil is the difference between the market price of the barrel and the adjusted base price of the barrel, which generally reflects the barrel's price prior to the expiration of federal price controls. Ibid.

46 The taxpayers conceded that the inclusion of their out-of-state production income in their apportionable tax base was appropriate under the "unitary business" principle. Reply Brief for Appellants 3, Amerada Hess, 109 S. Ct.1617; see text at notes 47-48 infra \& note 47 infra.

${ }^{47} \mathrm{~A}$ "unitary business" is an enterprise carried on across state limes in which the enterprise's in-state activities are sufficiently integrated with its out-of-state activities to give the state nexus with all the activities and to justify a state's tax upon an apportioned share of all the income generated by those activities. See Container Corp. of America v. Franchise Tax Bd., 463 U.S. 159, 163-69 (1983); Hellerstein, State Income Taxation of Multijurisdictional Corporations: Reflections on Mobil, Exxon, and H.R. 5076, 79 Mich. L. Rev. 113, 140-53 (1980). 
served that New Jersey had a substantial nexus with the activities that generated the oil companies' net income, including their out-ofstate oil-producing activities. ${ }^{48} \mathrm{New}$ Jersey's denial of a deduction for costs attributable to such out-of-state activity did not "alter the fact that New Jersey has a substantial connection to the oilproducing activity by virtue of the determination that this activity is conducted by a unitary business." 49

By relying on the undisputed fact that the oil compamies were conducting a unitary business in New Jersey and focusing on the question whether New Jersey had a sufficient nexus with the oil companies' income, the Court failed to confront squarely the taxpayers' point. To be sure, from a techmical standpoint, the demal of the windfall profit tax deduction simply increased the oil compames' unitary income tax base with which New Jersey had a sufficient nexus. Fron a practical standpoint, however, the denial of the windfall profit tax deduction was essentially indistinguishable from a tax imposed by New Jersey on a share of the windfall profit from the oil companies' out-of-state production. ${ }^{50}$

The critical nexus question, then, was whether "the practical effect" of the challenged tax, which purportedly informs the Court's Commerce Clause analysis, ${ }^{51}$ was more akin to an effort by New Jersey to tax out-of-state oil production or to the routine inclusion of income from a unitary business in the state's tax base. The answer to that question lies in the appropriate characterization of the windfall profit tax. If it is truly analogous to a severance tax, as the oil companies claimed, then there is force to their assertion that, by denying

\footnotetext{
${ }^{48} 109$ S.Ct. at 1621 .

${ }^{49} \mathrm{Ibid}$.
}

soFor example, assume that a taxpayer's federal windfall profit tax liability is $\$ 1$ million and that New Jersey's apportionable share of the taxpayer's income is 20 per cent. Under the New Jersey corporate income tax, the taxpayer was required to add $\$ 1$ million to its apportionable tax base, which is generally patterned after its federal income tax base, because the $\$ 1$ million had been subtracted from its federal tax base pursuant to I.R.C. $\$ 164(a)(5)$. Twenty percent of the $\$ 1$ million, or $\$ 200,000$ would be apportioned to New Jersey and New Jersey's 9 percent corporate income tax rate would be applied to produce an increased tax liability of $\$ 18,000$. If New Jersey had simply adopted its own "apportioned" windfall profit tax at 9 percent of the federal rate, the taxpayer's tax liability would be increased by 9 percent of the $\$ 1$ million federal tax liability or $\$ 90,000$. New Jersey's apportioned share of this figure would be 20 percent of $\$ 90,000$ or $\$ 18,000$, precisely the same increase in tax liability resulting from the addback of federal windfall profit taxes under the statutory procedure. See Brief for Appellants at 37 n.16, Amerada Hess, 109 S.Ct. 1637.

s'See Complete Auto Transit, 430 U.S. at 279; text at note 10 supra. 
a deduction for the windfall profit tax, New Jersey was in substance taxing out-of-state transactions under the guise of taxing unitary business income. Indeed, the Court has indicated that only the state in which mineral production occurs has sufficient nexus to impose a severance tax on such production: " the severance can occur in no other state' and 'no other state can tax the severance." 52 On the other hand, if the windfall profit tax may fairly be characterized as a levy on the oil compamies' unitary income rather than as a sitespecific expense, as New Jersey contended, ${ }^{53}$ then the Court was fully warranted in concluding that New Jersey's denial of a deduction for a cost associated with the earning of that incone did not amount in substance to a tax on an activity with which New Jersey lacked nexus.

Whatever the "true" nature of the federal windfall profit tax, an issue over which much ink has been spilled, ${ }^{54}$ the Court's holding without further explanation in Amerada Hess is troublesome. If a state as a matter of law has a substantial nexus with any expense associated with income derived from a unitary business carried on in the state, then states may be free to deny deductions which relate to exclusively out-of-state activity while at the same time taxing (under the unitary business principle ${ }^{55}$ ) income derived from those very same activities. This raises the specter of states skewing their demial of deductions so as to permit deductions for in-state activities while denying deductions for out-of-state activities. The objectionable aspects of such a practice may nore appropriately be analyzed under the Commerce Clause's fair apportionment or nondiscrimination criteria. ${ }^{56}$ Nevertheless, the Court could have limited the possibility of geographic skewing of deductions had it been willing to say that the Commerce Clause requires that states must have nexus with ac-

\footnotetext{
${ }^{52}$ Commonwealth Edison Co. v. Montana, 453 U.S. 609, 617 (1981).

${ }^{53}$ Brief for Appellee at 26-33, Amerada Hess, 109 S.Ct. 1617; id. at 1622 n.7.

${ }^{54}$ See, e.g., Attermeier \& Reveley, Characterizing the Windfall Profit Tax for State Incone Tax Purposes, 32 Oil \& Gas Tax Q. 465 (1984); Robison, The Misnamed Tax: The Crude Oil Windfall Profits Tax of 1980, 84 Dick. L. Rev. 589 (1980). As noted below, see text accompanying notes 80-81 infra, the oil companies had the better of the argument over the question whether the windfall profit tax should be characterized as a site-specific cost, even though the Court found it unnecessary to resolve the issue. Amerada Hes, $109 \mathrm{~S}$.Ct. at 1622 n.7.

${ }^{55}$ See note 46 supra.

56 These issues are addressed below. See text accompanying notes 75-82 and notes 96-100 infra.
} 
tivities whose costs are deducted from unitary income as well as with the unitary income itself.

\section{B. APPORTIONMENT}

The requirement that a tax affecting interstate commerce be fairly apportioned to the taxpayer's activities in the taxing state is venerable. ${ }^{57}$ It has acquired greater significance, however, as the Court's decisions have broadened the states' taxing powers. With the abandonment of the formal criteria that once created an irreducible zone of tax immunity for interstate commerce, ${ }^{58}$ the Court's emphasis has shifted from the question whether interstate commerce may be taxed at all to the question whether interstate commerce is being made to bear its fair share-or more than its fair share-of the state tax burden. If a tax is fairly apportioned to the taxpayer's activities in the taxing state, there is no risk, at least in principle, that a tax will subject a taxpayer engaged in interstate commerce to more than its fair share of the tax burden and expose it to a risk of multiple taxation not borne by local commerce.

Both of the Commerce Clause decisions rendered by the Court during its 1988 Term raised significant apportionment issues. In Goldberg, ${ }^{59}$ the taxpayers ${ }^{60}$ contended that Illinois' telecommunications tax violated the Commerce Clause's fair apportionment requirement because it was levied on the gross charge of each telephone call. They argued that the fair apportionment requirement compelled Illinois to include within its tax base only the portion of the gross charge of each interstate telecommunication that reflected the ratio of in-state activity to total activity associated with the telecommunication. They pointed to the apportionment formulas that the states have developed and the Court has approved for apportioning the tax bases of other instrumentalities of interstate commerce en-

\footnotetext{
57See, e.g., Pullman's Palace Car Co. v. Pennsylvania, 141 U.S. 18, 26 (1891); Maine v. Grand Trunk Ry., 142 U.S. 217, 278 (1891).

${ }^{58}$ See Complete Auto Transit, 430 U.S. 274; Hellerstein, State Taxation and the Supreme Court: Toward a More Unified Approach to Constitutional Adjudication?, 75 Mich. L. Rev. $1426,1441-46$ (1977).

${ }^{59}$ The facts of Goldberg are set out at text accompanying notes 31-36 supra.

${ }^{60}$ The named plaintiff, Goldberg, was a taxpayer whose liability arose out of the telephone calls charged to his service address. However, GTE Sprint Communications Corporation, whose challenge to the Illinois tax was also before the Court in a companion case (GTE Communications Corp. v. Sweet), was technically a tax collector rather than a taxpayer. For sake of simplicity, all challengers to the tax will be referred to as taxpayers.
} 
gaged in land, water, and air transportation, based on such factors as track mileage, ${ }^{61}$ barge line mileage, ${ }^{62}$ and revenue tons. ${ }^{63}$ By analogy, they claimed, Illinois was required to apportion taxable gross receipts from the interstate telecommunications by some equivalent ratio, such as the miles the electronic signals traveled within Illinois to the total miles traveled. ${ }^{64}$

The short answer to the taxpayers' claim was that Illinois did apportion its tax. By taxing only the receipts from calls originating or terminating in Illinois that were charged to an Illinois service address, ${ }^{65}$ Illinois effectively taxed only half the universe of interstate telecommunications originating or terminating in Illinois. This assumes, quite reasonably I believe, that roughly half of the calls originating or terminating in Illinois are charged to an Illinois service address with the other half charged to the service address of the caller in the other state in which the call originated or terminated. Since no states other than the state of origination or termination have the power to impose a tax on an interstate telecommunication-a fact made clear in the Court's nexus discussion ${ }^{66}$ - Illinois" "charged-toan-Illinois-service-address" limitation on its tax effected a 50 percent apportionment of the tax base to Illinois. Such an apportionment should satisfy constitutional strictures in a domain in which "rough approximation" rather than "precision" is the controlling standard. 67

The Court, however, took a nore circuitous route to the saine conclusion. Invoking the langnage of Container Corp. of America $v$. Francbise Tax Board, ${ }^{68}$ the Court viewed the fair apportionment requirement as triggering an inquiry into the question whether $a$ tax is "internally and externally consistent." 69 The Court's "internal consistency" test, which the Court has recently grafted onto the body of its Commerce Clause doctrine, ${ }^{70}$ requires that a tax "be structured so

${ }^{61}$ See, e.g., Pittsburgh, C., C. \& St. L. Ry. v. Backus, 154 U.S. 421 (1894).

${ }^{62}$ See, e.g., Ott v. Mississippi Valley Barge Line Co., 336 U.S. 169 (1949).

${ }^{63}$ Braniff Airways, Inc. v. Nebraska State Bd. of Equalization, 347 U.S. 590 (1947).

${ }^{64} 109$ S. Ct. at 588.

${ }^{65}$ See text accompanying notes 33-34 supra.

${ }^{6}$ See text accompanying notes 37-42 supra.

67Illinois Central R.R. v. Minnesota, 309 U.S. 157, 161 (1940).

68463 U.S. 159, 169-70 (1983).

69109 S.Ct. at 588.

70Seegenerally Hellerstein, Is "Internal Consistency" Foolish?: Reflections on an Emerging Commerce Clanse Restraint on State Taxation, 87 Mich. L. Rev. 138 (1988). 
that if every State were to impose an identical tax, no multiple taxation would result." 71 The Illinois levy plainly satisfied this standard. If every state confined its telecommunications tax levy to receipts from interstate telephone calls that were charged to an in-state service address, only one state would tax the receipts from each interstate call.

The Court then turned to the "external consistency" standard, which reflects familiar Commerce Clause doctrine requiring fair apportionment. Here the Court confronted a thornier problem. The Illinois tax was clearly unapportioned, in the sense that the tax applied to the gross charge of an interstate activity, and there was no formulary apportionment of the tax base to reflect in-state activity. The Court responded to this objection on several - and not wholly consistent-grounds. The tax was like a sales tax and did not need to be apportioned; the tax was fairly apportioned because it created little risk of multiple taxation; the tax created some risk of multiple taxation, but provision of a tax credit eliminated the possibility of actual multiple taxation; and true apportionment of the tax base, on a mileage or other geographic basis, was administratively and technologically impossible in light of the complexity of contemporary telecommunications networks. ${ }^{72}$

As indicated above, I have no quarrel with the Court's conclusion that the Illinois tax was fairly apportioned. ${ }^{73}$ It is unfortunate, however, that the Court failed to embrace the most straightforward response to the fair apportionment claim. Each of the justifications the Court advanced for its conclusion that the Illinois tax was fairly apportioned has weaknesses, ${ }^{74}$ and they may come back to haunt the

${ }^{71}$ Goldberg, 109 S.Ct. at 589.

72Id. at 589-91.

${ }^{73}$ See text accompanying notes 65-67 supra.

${ }^{74}$ (1) Tbe tax was like a sales tax and did not need to be apportioned. It is true that the tax had many of the characteristics of a retail sales tax in that it was assessed on the individual consumer, it was measured by the price of the service sold, and it was collected by the retailer. It is also true that retail sales taxes generally are not apportioned. As I have explained in detail elsewhere, however, our tolerance of unapportioned sales taxes is largely a creature of administrative necessity and represents no more than a second-best solution to the fair apportionment of receipts from an interstate transaction over which more than one state may legitimately exercise taxing power. See Hellerstein, note 70 supra, at 170-88. Moreover, the Court has unjustifiably extended its tolerance of unapportioned retail sales taxes to unapportioned business gross receipts taxes. Ibid. Because the line between retail sales taxes and general business gross receipts taxes is not always clcar (at least to the Court), and because there is a risk that the Court may extend its analysis of the retail gross receipts tax in Goldberg to the business gross receipts taxes that many states impose on telecommunications and other public service companies, it would have been better if the Court had not put its imprimatur upon an unapportioned levy in this context. 
Court in other contexts. As some of us instruct our law students on exams, a good short answer will receive a higher grade than an equally good longer answer.

The Court did give a short answer to the apportionment question raised by Amerada Hess. ${ }^{75}$ Unfortunately, this question required a longer answer. The gravamen of the oil companies' claim was that New Jersey, by denying a deduction for an out-of-state expense (the windfall profit tax), geographically skewed their apportionable income to assign more income to New Jersey than was fairly attributable to their activities in the state. The Court's response was essentially a reiteration of its rationale for rejecting the taxpayer's nexus claim: ${ }^{76}$ "[F]or apportionment purposes, it is mappropriate to consider the windfall profit tax as an out-of-state expense. Rather, just as each appellant's oil-producing revenue as part of a unitary business is not confined to a single State, so too the costs of producing this revenue are unitary in nature." 77

The problem with the Court's answer is that it assumes, as a matter of federal constitutional law, that all expenses of a umitary busi-

(2) The tax was fairly apportioned because it created little risk of multiple taxation. As I have explained elsewhere, see Hellerstein, note 70 supra, at 185 , this is essentially a non sequitur. While it is true that the fair apportionment requirement is designed to prevent multiple taxation, it does not follow that any tax that does not create the risk of multiple taxation is fairly apportioned. Wholly apart from its role in preventing multiple taxation, the fair apportionment criterion serves to limit the territorial reach of state tax power by requiring that the state's tax base correspond to the taxpayer's in-state presence. Norfolk \& Western Ry. v. Missouri State Tax Comm'n, 390 U.S. 317, 323-35 (1968). There may be cases in which a state's tax creates no risk of multiple taxation but nevertheless involve unquestioned extraterritorial taxation (e.g., if a state sought to tax the unapportioned income of all corporations doing business in the state, but granted a credit for other states' taxes). In such cases, it is important that we not lose sight of the fact that there is more to the fair apportionment criterion than avoiding the risk of multiple taxation. The Court's opinion is unhelpful in that respect.

(3) The tax created some risk of multiple taxation, but provision of a tax credit eliminated tbe possibility of actual multiple taxation. As suggested in (2) above and as I have argued elsewhere, see Hellerstein, note 70 supra, at 182-88, the provision of a tax credit does not make an unapportioned tax "fairly apportioned," even though it may deal with the multiple taxation issue. The Court's opinion may lead some readers to the opposite conclusion.

(4) True apportionment of the tax base, in tbe sense of division of the tax base on a mileage or otber geograpbic basis, was administratively and technologically impossible in ligbt of tbe complexity of contemporary telecommunications networks. As noted above, see text accompanying notes 65-67 supra, this conclusion is essentially untrue in light of the possibility of dividing the tax base on a fiftyfifty split between the state of the calls' origin and destination. Moreover, it may encourage states to adopt crude approaches to apportionment of technologically complex industries (e.g., financial services) when in fact more precise ways of mcasuring in-state presence are fcasible. See, e.g., the Multistate Tax Commission's Proposed Regulations for Apportioning the Income of the Financial Services Industry, 1989 Multistate Tax Comm'n Rev. 17 (March 1989).

${ }^{75}$ The facts of Amerada Hess are set out at text accompanying notes $44-45$ supra.

76 See text accompanying notes $47-49$ supra.

77109 S. Ct. at 1622. 
ness bear the same relationship to that business as does the income from the business. By hypothesis, then, such expenses are deemed to constitute an inextricable coinponent of the unitary business that cannot be separately identified on a geographic basis. ${ }^{78}$ But this assumption is unwarranted. It may well be that unitary income, as the Court effectively defined it in the very first case challenging the constitutionality of formulary apportionment, is generated by a "series of transactions" beginning with "manufacture" or production in one state and "ending with sale in other states" so that"

[t]he Legislature, in attempting to put upon this business its fair share of the burden, of taxation was faced with the impossibility of allocating specifically the profits earned by the processes conducted within its borders.

It does not follow, however, that all the expenses of producing that incone are equally difficult to identify on a geographic basis. To be sure, nrany expenses, such as the costs of centralized services or interest payments on company-wide debt, would generally be as difficult to segregate on a geographic basis as the income these expenses helped to generate. Other expenses, however, such as local real estate taxes, clearly can be so segregated.

The mere fact that soine expenses can be identified on a geographic basis does not niean that a denial of a deduction for those expenses raises concerns about unfair apportionment. For example, if a state denied a deduction for local real estate taxes no inatter where incurred, the increase in the apportionable tax base, and hence in taxable income, would not implicate the fair apportionment criterion. There is nothing in the disallowance of such a deduction that would systematically distort the relationship between the income apportioned to the state and the activities carried on there.

When, on the other hand, an expense can be identified on a geographic basis and that expense is associated exclusively with out-ofstate activity, the denial of a deduction for the expense from unitary inconie does raise serious concerns about unfair apportionment. The inexorable effect of denying the expense deduction is to increase the portion of unitary income attributable to out-of-state activity. When the income is apportioned to the deduction-denying state, the result is the inclusion of a disproportionate component of out-of-state

\footnotetext{
${ }^{78}$ See note 47 supra.

${ }^{79}$ Underwood Typewriter Co. v. Chamberlain, 254 U.S. 113, 120 (1920).
} 
values in the tax base and the taxation of income that is necessarily greater than can fairly be attributed to in-state business activities.

If, then, the windfall profit tax constitutes an exclusively out-ofstate expense, a persuasive case can be inade that New Jersey's demial of a windfall profit tax deduction violated the fair apportionment criterion. The Court never reached this question beeause of its view that "[f]or fair apportionment purposes, the relevant question is whether the windfall profit tax is a cost of a unitary business, rather than what the attributes of that cost may be." 80 Nevertheless, the taxpayers had the better of the argument over the question whether the windfall profit tax is in fact is a site-specific cost that is incurred exclusively outside of New Jersey. It is imposed on a specific activity - the removal of taxable crude oil-that occurs at a geographically identifiable location, and it has many of the earmarks of a severance tax, which the Court itself has characterized as sitespecific. $^{81}$

Does this mean that the Court erred in failing to strike down New Jersey's tax as unfairly apportioned? Not necessarily. First, even if the Court had recognized the flaws in New Jersey's taxing scheme, it might still have concluded (as it did in Amerada Hess) that the taxpayers failed to carry the burden of proving unfair apportionment by demonstrating "that there is no rational relationship between the income attributed to the State and the intrastate values of the enterprise." 82 Second, the Court nuay have declined to adopt a rule condemning the disallowance of out-of-state expense deductions for sound institutional reasons. Adoption of such a rule would have required courts to determine whether a whole array of routine tax deductions pass constitutional nuster (such as deductions for depletion or for intangible drilling costs). Moreover, unless the Court had limited its holding to eases involving exclusively out-of-state expenses, courts would have been saddled with the task of determining the level of disallowed in-state expense deductions that would insulate the disallowance of an out-of-state expense deduction from constitutional attack. The inere prospect of overseeing the developinent of such a body of ease law may have dissuaded the Court from authorizing an inquiry into these questions.

\footnotetext{
${ }^{80}$ Amerada Hes, 109 S.Ct. at 1622 n.7.

81 See text at note 52 supra.

${ }^{82}$ Amerada Hes, 109 S.Ct. at 1622 (quoting Container, 463 U.S. at 180).
} 


\section{DISCRIMINATION}

The rule forbidding state taxes that discriminate against interstate commerce has been a central tenet of the Court's Commerce Clause doctrine ever since the Court invoked the Clause more than a century ago as the basis for invalidating a state tax.$^{83}$ Although the concept of discrimination is not self-defining and the Court has never precisely delineated the scope of the prohibition against discriminatory taxes, the essential meaning of discrimination as a criterion for adjudicating the constitutionality of state taxes affecting interstate commerce emerges unmistakably from the Court's numerous decisions addressing the issue: a tax that by its terms or operation imposes greater burdens on out-of-state goods, activities, or enterprises than on competing in-state goods, activities, or enterprises will be struck down as discriminatory under the Commerce Clause.

In Goldberg, the taxpayers claimed that Illinois' 5 percent tax on the gross receipts from interstate telecommunications discriminated against interstate commerce, despite the existence of an identical 5 percent tax on intrastate telecommunications, because interstate calls bore a relatively heavier tax burden than intrastate calls. The argument can best be understood by illustration, which Justice Stevens provided in his concurring opinion: ${ }^{84}$

A call originating in and terminating in Illinois that costs $\$ 10$ is taxed at full value at $5 \%$. A second call, originating in Illinois but terminating in Indiana, costs the same $\$ 10$ and is taxed at the same full value at the same $5 \%$ rate. But while Illinois may properly tax the entire $\$ 10$ of the first call, it (technically) inay tax only that portion of the second call over which it has jurisdiction, namely, the intrastate portion of the call (say, for example, $\$ 5$ ). By imposing an identical $50 \notin$ tax on the two calls, Illinois has imposed a disproportionate burden on the interstate call.

The Court's reasoning dismissing the taxpayers' argument was unpersuasive. The Court first noted that the Illinois tax was distinguishable from Pennsylvania's flat trucking taxes it had recently invalidated because the levies bore more heavily on interstate trucks than intrastate trucks. ${ }^{85}$ The former traveled fewer miles on state highways than the latter and, as a consequence, interstate trucks were subjected to a higher per-mile charge than the intrastate trucks

\footnotetext{
${ }^{83}$ See Welton v. Missouri, 91 U.S. 275 (1876).

${ }^{84} 109$ S.Ct. at 593 (Stevens, J., concurring).

${ }^{85}$ American Trucking Ass'ns, Inc. v. Scheiner, 483 U.S. 266 (1987).
} 
for exercising the same privilege. The point of distinction the Court perceived between the Pennsylvania and Illinois taxes was that Pennsylvania's taxes burdened out-of-state truckers, who would have difficulty effecting legislative change, whereas Illinois' tax burdened local consumers, who presumably had access to the political process. ${ }^{86}$ "It is not the purpose of the Commerce Clause," the Court declared, "to protect state residents from their own state taxes." 87

Surely the Court cannot have meant what it said. If Illinois had imposed a tax on state residents' purchases of out-of-state but not instate goods, the tax would have been struck down in short order. A more blatant discrimination against interstate commerce in violation of the "free trade" principles underlying the Commerce Clause is difficult to imagine. It is a cardinal purpose of the Commerce Clause to protect state residents from their own state taxes when those taxes discriminate against interstate Commerce. Justice Stevens recognized this point in his concurring opinion. 88 One would hope that upon further reflection, the Court will repudiate its careless remark.

The Court's second ground for dismissing the taxpayers' discrimination claim was that, in contrast to the measurable indicia of local presence reflected by the trucks' mileage on state highways which provided the Court with a basis for finding that the Pennsylvania highway taxes bore more heavily on out-of-state than local trucks, "the exact path of thousands of electronic signals can neither be traced nor recorded." 89 It "therefore" followed that the tax did not discriminate against interstate commerce. ${ }^{90}$ Despite the Court's professed inability to identify the anıount of discrimination, if any, that resulted from the Illinois levy, one suspects that there is in fact some discrimination if one analyzes the issue in terms of the example set forth above. ${ }^{91}$ Moreover, the Court has declared that "we need not know how unequal the Tax is before concluding that it unconstitutionally discriminates." 92

The more conpelling response to the discrimination claim was that the taxpayers' argument proceeded on a false premise, namely,

\footnotetext{
${ }^{86} 109$ S.Ct. at 591 .

${ }^{87}$ Ibid.

${ }^{88}$ Id. at $592-93$.

89Id. at 591 .

oIbid.

915ee text at note 84 supra.

92Maryland v. Louisiana, 451 U.S. 725, 760 (1981).
} 
that the discrimination issue should be analyzed solely in terms of calls that Illinois actually seeks to tax because they are charged to an Illinois service address. If one instead analyzes the issue in terms of the entire universe of calls originating and terminating in Illinois, only about one-half of which Illinois seeks to tax, the discrimination claim evaporates. ${ }^{93}$ Justice Stevens, referring to the example set forth above, ${ }^{94}$ put it this way: ${ }^{95}$

Although Illinois taxes the entirety of every call charged to an Illinois number, it does not tax any part of the calls that are received at an Illinois number but charged elsewhere. Thus, although Illinois taxes the entire Illinois-Indiana $\$ 10$ call, it taxes no part of the reciprocal Indiana-Illinois $\$ 10$ call. At the $5 \%$ rate, Illinois receives $50 \&$ from the two calls combined, precisely the amount it receives from one $\$ 10$ purely intrastate call. By taxing half the relevant universe of interstate calls at full value, Illinois achieves the same economic result as taxing all of those calls at half value would achieve. As a result, interstate phone calls are taxed at a lower effective rate than intrastate calls, and accordingly bear a proportional tax burden.

In Amerada Hess, the taxpayers' constitutional attack on New Jersey's denial of a windfall profit tax deduction was easily cast in the form of an argument that the tax discriminated against interstate commerce. The alleged effect of the statutory scheme was to single out for special tax burdens a form of business activity that is conducted only in other jurisdictions. The levy therefore imposed a discriminatorily higher effective tax burden on out-of-state than on local business. ${ }^{96}$

Thus framed, however, the taxpayers' argument suffered from a lack of evidence that New Jersey had intentionally or explicitly singled out the windfall profit tax for invidious treatment. Indeed, the statute, which denied a deduction for " $[t]$ axes paid or accrued to the United States on or measured by profits or income, ${ }^{97}$ was drafted long before the windfall profit tax was enacted in 1980. Moreover, it was applied to deny a deduction for federal income taxes. Hence it

\footnotetext{
${ }^{93}$ The fair apportionment claim collapsed in a similar fashion when it was viewed in the context of the entire universe of interstate telephone calls originating and terminating in Illinois. See text accompanying notes 65-67 supra.

${ }^{94}$ See text at note 84 supra.

${ }^{95} 109$ S.Ct. at 593 (Stevens, J., concurring).

${ }^{96}$ See Brief for Appellants 41-49, Amerada Hess, 109 S.Ct. 1617.

97N.J. Stat. Ann. § 54:10A-4(k)(West 1986).
} 
could not be argned that the statute by its terms or by design discriminated against interstate commerce.

It is well settled, of course, that the Commerce Clause proscribes taxes that, though nondiscriminatory on their face, nevertheless discriminate against interstate commerce by their practical operation. ${ }^{98}$ If denying the windfall profit tax deduction in practical effect disallows the deduction of an out-of-state expense, and there is no comparable in-state expense whose deduction is disallowed, then it would seem that a prima facie case of state tax discrimination has been stated. The Court found, however, that no such claim had been stated. Its determination rested largely on the basis of the questionable conclusion that the windfall profit tax was comparable to the federal income tax-or at least that it was not "irrational or arbitrary" for New Jersey so to consider the tax. ${ }^{99}$ If the windfall profit tax is viewed as comparable to the federal income tax, it undermines the contention that out-of-state expense and business activity has been singled out for discriminatory treatment because the federal income tax is not an exclusively out-of-state expense. Once the Court rejected the taxpayers' premise that the New Jersey statute singled out the windfall profit tax for a deduction demal, it could leave for another day the question "whether a statute that did so would impermissibly discriminate against interstate commerce."100

\section{FAIR RELATION BETWEEN THE TAX AND THE SERVICES PROVIDED BY THE STATE}

The first three prongs of the Court's contemporary Commerce Clause standard-substantial nexus, fair apportionment, and nondiscrimination-were familiar concepts deeply embedded in the Court's doctrine for years before Complete Auto Transit was handed down in 1977. By contrast, the fourth prong-the requirement that

98See, e.g., Nippert v. City of Richmond, 327 U.S. 416, 431 (1946); Best \& Co. v. Maxwell, 311 U.S. 454,456 (1940).

99 Amerada Hes, 109 S.Ct. at 1623 n.9. The Court based its conclusion on the facts that the wind fall profit tax was intended to reach only the excess income derived from oil production as a result of decontrol, that the "net income limitation" assured that the tax was imposed only on receipts above cost, and that the Internal Revenue Service characterized the structure of the tax as more akin to an income tax than to an excise tax. Ibid. Most other observers, however, including the Solicitor General, are of the view that the windfall profit tax more closely resembles an ordinary severauce tax than the federal income tax. See Brief for the United States as Amicus Curiae in support of Juris. Statement 24-27; Attermeier \& Reveley, note 54 supra; Robison, note 54 supra.

${ }^{100}$ Amerada Hess, 109 S.Ct. at 1624. 
a tax be "fairly related to the services provided by the State"101_was an uncertain, if not an unknown, quantity when the Court articulated it along with the other three Commerce Clause criteria in Complete Auto Transit. Read literally, the Court's language could have been taken as contemplating a detailed factual investigation into the specific benefits the state provided to the taxpayer to ascertain whether the value of the benefits bore a reasonable relationship to the amount of the tax imposed. With the exception of cases involving state-imposed user charges, ${ }^{102}$ however, no such detailed factual investigation had ever been required by the Court in determining the validity of a tax under the Commerce Clause. Moreover, language in several of its opimions following on the heels of Complete Auto Transit suggested that the "fairly related" standard would be satisfied so long as the state provided the taxpayer with "the benefits of a trained work force and the advantages of a civilized society."103

In Commonwealth Edison Co. v. Montana, ${ }^{104}$ which considered a challenge to Montana's 30 percent coal severance tax, the Court lifted the shroud of uncertainty that had obscured the meaning of the "fairly related" test and made it clear that the test was not an invitation to judicial review of taxes for excessiveness. The Court held that the relevant inquiry under the "fairly related" test is whether the tax is reasonably related to the extent of the taxpayers' contact with the state, "since it is the activities or presence of the taxpayer in the State that may properly be made to bear a 'just share of state tax burden.' "105 Justice Blackmun, the author of Complete Auto Transit, vigorously dissented from the Court's view of the meaning of the "fairly related" test, asserting that the Court had "emasculated" the fourth prong and left it utterly without meaning. ${ }^{106}$

Cases following Commonwealth Edison vindicate Justice Blackmun's complaint. The "fairly related" test appears to have little independent significance as a restraint on state tax power. Any tax held to violate the "fairly related" test is likely to flunk some other portion of

\footnotetext{
${ }^{10}$ Complete Auto Transit, 430 U.S. at 279.

${ }^{102}$ See, e.g., Evansville-Vanderburgh Airport Authority District v. Delta Airlines, 405 U.S. 707 (1972).

${ }^{103}$ Japan Line, Ltd. v. County of Los Angeles, 441 U.S. 434, 445 (1979); see also Department of Revenue v. Association of Washington Stevedoring Cos., 435 U.S. 734, 750-5 1 (1978).

104453 U.S. 609 (1981).

105Id. at 626 (quoting Western Live Stock v. Bureau of Revenue, 303 U.S. 250, 254 (1938)).

106Id. at 645 (Blackmun, J., dissenting).
} 
the Court's Commerce Clause standard as well. ${ }^{107}$ And it is hard to conceive of any tax that would satisfy the substantial nexus, fair apportionment, and nondiscrimination criteria that would not also satisfy the "fairly related" test. ${ }^{108}$

Goldberg and Amerada Hess reinforce this conclusion. The Court had little difficulty in concluding that both levies, which had already passed the first three prongs of the Court's Commerce Clause test, likewise passed the fourth. In Goldberg, the Court observed that "[t]he fourth prong of the Complete Auto test focuses on the wide range of benefits provided to the taxpayer, not just the precise activity connected to the interstate activity at issue." 109 Illinois telephone consumers received numerous benefits from Illinois, including "police and fire protection as well as the other general services provided by the State."110 The Illinois telecommunications tax therefore survived constitutional scrutiny, if it can be called that, under the "fairly related" test. The Court similarly concluded that New Jersey's corporate incone tax was "fairly related" to the services provided by the state in light of the benefits provided by New Jersey " which include police and fire protection, the benefits of a trained work force and "the advantages of a civilized society." "111

107Thus in American Trucking Associations, Inc. v. Scheiner, 483 U.S. 266, 291 (1987), the only case in which the Court has invoked the "fairly related" test in striking down a state tax, the flat tax on trucks was also held to violate the Commerce Clause's nondiscrimination requirement.

${ }^{108}$ None exists to iny knowledge.

${ }^{109} 109$ S.Ct. at 592.

I10Ibid.

11 Amerada Hes, 109 S.Ct. at 1624 (quoting Exxon Corp. v. Wisconsin Department of Revenue, 447 U.S. 209, 228 (1980) (quoting Japan Line, Ltd, 441 U.S. at 445)).

The only other case touching on the Commerce Clause during the Court's 1988 Term was Cotton Petroleum Corp. v. New Mexico, 109 S. Ct. 1698 (1989), where the Court held that New Mexico conld validly impose severance taxes on oil and gas extracted from Indian lands by non-Indian lessees despite the fact that the Indian tribe imposed similar taxes on the same oil and gas production. In so holding the Court rejected the argument that the tax imposed a multiple burden on interstate commerce. It reasoned that until Congress provides otherwise, both the tribe and the state had taxing jurisdiction over the taxpayer's oil and gas leases. Id. at 1714. It also rejected the claim that the state tax exceeded the benefits provided to the taxpayer, observing that "there is no constitutional requirement that the benefits received from a taxing authority by an ordinary commercial taxpayer-or by those living in the community where the taxpayer is located - must equal the amount of its tax obligations." Ibid. Finally, the Court held that a tribe should not be treated as a state under the Commerce Clause for purposes of determining whether the state's tax mnst be fairly apportioned: "[T]he fact that States and tribes have concurrent jurisdiction over the same territory makes it inappropriate to apply Commerce Clause doctrine developed in the context of commerce 'among' States with inutually exclusive territorial jurisdiction to trade "with' Indian tribes." Id. at 1716. 


\section{The Due Process Clause}

The Supreme Court has construed the Due Process Clause as a limitation on the territorial reach of the states' taxing powers. ${ }^{112}$ The Due Process Clause, like the Commerce Clause, has been construed to require that the state have a minimum connection or nexus with the person, property, or transaction it seeks to tax, and that the measure of the tax fairly reflect the taxpayer's activities in the state, i.e. that it be fairly apportioned. On numerous occasions the Court has recognized that the requirements of the Commerce and Due Process Clauses in the nexus and apportionment contexts are substantially the same. ${ }^{113}$ In Amerada Hess, the Court reiterated that "the Complete Auto test encompasses due process standards." 114 Thus in the only due process challenge to a state tax it considered during its 1988 Term, the Court declared that because New Jersey's income tax "passes all four prongs of the Complete Auto test, we also conclude that it does not violate due process." 115

\section{The Equal Protection Clause}

In light of the broad leeway the states enjoy under the Equal Protection Clause in drawing lines for tax purposcs "when no specific federal right, apart from equal protection, is imperiled,"116 it may come as somewhat of a surprise that the Court has invalidated a number of state taxes on equal protection grounds in recent years. In the space of single year, the Court relied on the Equal Protection Clause to strike down a gross premiums tax discriminating against out-of-state insurers, ${ }^{117}$ a use tax credit limited to residents for sales taxes paid to other states, ${ }^{118}$ and a property tax exemption limited to

${ }^{112}$ The Court first invoked the Due Process Clause as a prohibition of extraterritorial taxation in Louisville \& Jeffersonville Ferry Co. v. Kentucky, 188 U.S. 385, 398 (1903). See Central Railroad Co. v. Pennsylvania, 370 U.S. 607, 620 (1962) (Black, J., concurring).

${ }^{113}$ See, e.g., National Bellas Hess v. Department of Revenue, 386 U.S. 753, 756 (1967) (nexus); Ott v. Mississippi Valley Barge Line Co., 336 U.S. 169, 174 (1949) (apportionment).

${ }^{114} 109$ S.Ct. at 1625.

115 Ibid.

${ }^{116}$ Lehnhausen v. Lake Shore Auto Parts Co., 410 U.S. 356, 359 (1973); see also Exxon Corp. v. Eagerton, 462 U.S. 176, 196 (1983) ("'l] egislatures have especially broad latitude in creating classifications and distinctions in tax statutes"').

${ }^{117}$ Metropolitan Life Insurance Co. v. Ward, 470 U.S. 869 (1985).

118Williams v. Vermont, 472 U.S. 14 (1985). 
Vietnam veterans who were residents of the state prior to a certain date. 119

Perhaps these decisions can be explaimed by the fact that they raised serious concerns of interstate federalism and therefore fell within the exception to the Court's generally relaxed oversight of state tax classifications. To be sure, this explanation flies in the face of the Court's position that the Equal Protection Clause should not . be construed as an "instrument of federalisin." 120 It also runs counter to the Court's declaration that discrimination against out-of-state interests need only be rationally related to a legitimate state purpose to survive equal protection scrutiny. ${ }^{121}$ Yet, it is difficult to make sense of these decisions except as heightened judicial scrntiny masquerading as "rational basis" analysis. 122

The Court's most recent decision striking down a state taxing scheme under the Equal Protection Clause, however, cannot be explained on these grounds. Allegbeny Pittsburgb Coal Co. v. County Commission ${ }^{123}$ involved neither suspect classifications nor fundamental rights, and no specific federal interest, apart from equal protection, was jeopardized. Allegheny concerned a challenge to gross disparities in ad valorem property tax assessinents resulting from the practice of assessing property based on its recent sales price. Like many taxing jurisdictions across the country, Webster County, West Virginia, relied on sales prices of recently conveyed property in determining its value for ad valorem tax purposes and did not systematically adjust the assessment of unsold comparable properties to reflect current value. So long as property was unsold, it remamed on the tax rolls with the same assessment it bore in prior years, with only minor and infrequent adjustments. As a consequence, recently conveyed property was often assessed at a much higher percentage of its fair market value than was comparable property that had not recently been sold. Indeed, the record in Allegheny revealed that the taxpayers' property-consisting of coal-bearing lands-was as-

${ }^{119}$ Hooper v. Bernallilo County Assessor, 472 U.S. 612 (1985).

${ }^{120}$ Western \& Southern Life Ins. Co. v. State Bd. of Equalization, 451 U.S. 648,667 n. 21 (1981).

121 Ibid.

122See Cohen, Federalism in Equality Clothing: A Comment on Metropolitan Life Insurance Company v. Ward, 38 Stan. L. Rev. 1 (1985).

${ }^{123} 109$ S.Ct. 633 (1989). 
sessed at approximately eight to 35 times more than comparable neighboring properties. ${ }^{124}$

In a brief opinion, the Court sustained the taxpayers' claim that the county's assessment practice violated the Equal Protection Clause. While reiterating the well-entrenched principle that the states have broad powers under the Clause to impose different types of taxes upon different types of taxpayers and property, the Court observed that the county assessor made no attempt to justify the disparities in assessment on the ground that recently sold and unsold property constituted two different classes of property that were to be taxed differently according to deliberate state policy. Indeed, the opposite was true: West Virginia's constitution and implementing statutes provided that all the property in question was to be taxed at a uniform rate throughout the state according to its value. Given the state's own professed adherence to a standard of uniformity and equality of property assessments based on market value, the county assessor's reliance on actual sales prices as the basis for achieving such equality could not be justified as a state-sanctioned classification scheme.

Nor could the practice be viewed as a mere "transitional delay in adjustment of assessed value" 125 or as one of those "occasional errors or state law or mistakes in judgment"126 that the Equal Protection Clause would tolerate. In contrast to a program of generalized adjustments in property values designed to equalize the value of properties for short periods without the necessity of reappraising every parcel every year, the assessor's occasional adjustments to the assessment of unsold property were "too small to seasonably dissipate the remaining disparity between these assessments and the assessments based on a recent purchase price." 127 Moreover, the assessor's practice that produced the disparate assessments was "intentional" 128 and "systematic"129 and therefore could not be dismissed as a permissible error in judgment.

From a doctrinal perspective, the Court's opinion in Allegheny is unexceptional. It is settled law that "intentional systematic under-

\footnotetext{
124Id. at 638 .

$125 \mathrm{Ibid}$.

126Ibid.

${ }^{127}$ Ibid.

128 Ibid.

129 Ibid.
} 
valuation by state officials of other taxable property in the same class contravenes the constitutional right of one taxed upon the full value of his property." 130 In light of the Court's determination that the discriminatory assessinents resulted from "intentional systematic undervaluation" by the county assessor and that the property in question was considered by West Virginia to fall within a single class, it followed as a matter of course that the taxpayers had been denied equal protection. 131

From a practical perspective, however, the Court's holding has considerable significance. There are hundreds of taxing jurisdictions throughout the nation with "methods" of achieving equality annong different parcels that are essentially indistinguishable from that of Webster County, West Virginia. Assessments from such jurisdictions would appear to be vulnerable to equal protection challenge, at least if disparities of the nuagnitude that were proven in Allegbeny can be denionstrated elsewhere. ${ }^{132}$

The Court's decision in Allegheny also raises serious questions about the constitutionality of California's Proposition 13. ${ }^{133}$ Proposition 13 amended the state constitution to limit property taxes to 1 percent of 1975-76 valuations and to prohibit annual increases in valuations of more than 2 percent, unless the property is sold. The Court was well aware of the potential inplications of its decision for California's taxing systen, and observed in a footnote: ${ }^{134}$

We need not and do not decide today whether the Webster County assessment method would stand on a different footing if it were the law of a State, generally applied, instead of the aberra-

${ }^{130}$ Sunday Lake Iron Co. v. Wakefield, 247 U.S. 350, 352-53 (1918). See also Sioux City Bridge Co. v. Dakota County, 260 U.S. 441, 445-46 (1923); Cumberland Coal Co. v. Board of Revision of Tax Assessments, 284 U.S. 23, 28-29 (1931); Hillsborough v. Town of Cromwell, 326 U.S. 620 (1946).

${ }^{131}$ The Court also held, in line with established precedent, see cases cited in note 130 supra, that the taxpayers could not be relegated to the remedy of seeking to have the assessinents of the undervalued property raised, as the West Virginia Supreme Court had suggested. In re 1975 Tax Assessments against Oneida Coal Co., 360 S.E.2d 560, 565 (W. Va. 1987). Rather they were entitled under the Equal Protection Clause to have their assessments reduced to the level at which comparable properties were assessed.

${ }^{132}$ See, e.g., Township of West Milford v. Van Decker, 235 N.J. Super. 1, 561 A.2d 607 (1989) (increased asessment of property based on sales price violates federal and state constitutions); Krugman v. Village of Atlantic Beach, 121 A.D.2d 175, 533 N.Y.S.2d 495 (2d Dep't 1988) (assessor's practice of selective reassessment of ouly those properties in the taxing district that were sold during the prior year contravenes statutory and constitutional mandates).

${ }^{133}$ Cal. Const. art. XIIIA, $\$ 2$.

${ }^{134} 109$ S.Ct. at 638 n.4. 
tional enforcement policy it appears to be. The State of California has adopted a similar policy. . . popularly known as "Proposition 13.". . : The system is grounded on the belief that taxes should based on the original cost of property and should not tax unrealized paper gains in the value of property.

The Court appears to be suggesting that Webster County's discrimination against recently purchased property may be distinguishable from California's because the former reflected the "aberrational" actions of a single assessor, contrary to the policy of West Virginia to tax all property equally, whereas the latter reflects the considered policy of a state. But one has to ask which way that distinction cuts. Is the Equal Protection Clause less offended by discrimination that reflects deliberate state policy than by discrimination resulting from the aberrational conduct of a single individual?

Although as an original proposition one might have thought not, an affirmative answer to this question is deeply rooted in equal protection doctrine. The Equal Protection Clause, after all, only protects against unjustifiable discrimination. If "rational basis" is the standard of justification, as it is in the context of tax classifications that do not implicate federal concerns apart from equal protection, ${ }^{135}$ then if the discrimination has a "rational basis," as it arguably does in California, it will pass muster under the Equal Protection Clause. ${ }^{136}$

Assuming that California's ad valorem property tax system would survive scrutiny under the Equal Protection Clause, ${ }^{137}$ it raises a se-

\footnotetext{
${ }^{135}$ Because the practice of reassessing property based on recent sales will bear disproportionately on newcomers to the taxing jurisdiction, including those who have moved from other states, one could argue that such a practice does in fact raise federalism concerns, thus triggering a higher standard of equal protection scrutiny. See Shapiro v. Thompson, 394 U.S. 618 (1969); Indeed, as suggested above, see text accompanying notes 116-22 supra, the Court has been inclined to strike down taxing schemes that threaten federalism interests even under a "rational basis" analysis. See cases cited in notes 117-19 supra; see also Zobel v. Williams, 457 U.S. 55 (1982).

${ }^{136}$ But see note 135 supra. Writing without the benefit of the Supreme Court's guidance in Allegbeny, the California Supreme Court dismissed a constitutional challenge to Proposition 13 on equal protection and other grounds. Amador Valley Joint Union High School District v. State Board of Equalization, 22 Cal. 3d 318, 149 Cal. Rptr. 239, 583 P.2d 1281 (1981). The Court distinguished the principal cases underlying the Allegbeny decision, see cases cited in note 130 supra, on the ground that those cases "involved constitutional or statutory provisions which mandated the taxation of property on a current valne basis" and they "do not purport to confine the states to a current value system under equal protection principles." $22 \mathrm{Cal}$. 3d at 235,149 Cal. Rptr. at 251, 583 P.2d at 1293 . No review of this decision was sought in the United States Supreme Court.

${ }^{137} \mathrm{~A}$ definitive resolution of this issue is possible in due course. See Northwest Financial, Inc. v. San Diego County, Cal. Super. Ct., San Diego Cty., No. 611092, filed April 12, 1989 (challenging the constitutionality of Proposition 13 in light of Allegbeny).
} 
ries of additional questions bearing on the relationship between a taxpayer's federal right to equal protection and the underlying state classification scheme. If a state can classify property for ad valorem tax purposes on the basis of sales price, then, as the Court has stated in an analogous context, "the only question relevant for us is whether the state has done so." 138 The Court's conclusion in Allegbeny, of course, was based on its determination that the state had not done so. ${ }^{139}$ Does this mean, however, that if West Virginia tomorrow were formally to adopt an ad valorem tax system based on recent sales prices that the preexisting practice of the Webster County assessor would satisfy equal protection strictures? Apparently so, assuming the constitutionality of Proposition 13.

But why should the result be any different merely because the classification in West Virginia was de facto rather than de jure? As the Court declared in Nashville, C. \& St. L. Ry. v. Browning, ${ }^{140}$ in dismissing an equal protection challenge by a railroad to the valuation of its property which was overvalued by comparison to the valuation of other property in Tennessee: ${ }^{141}$

If the discrimination of which the Railway complains had been formally written into the statutes of Tennessee, a challenge to its constitutionality would be frivolous. If the state supreme court had construed the requirement of uniformity in the Tennessee Constitution so as to permit recognition of these diversities, no appeal could successfully be made to the Fourteenth Amendment. Here ... all the organs of the state are conforming to a practice, systematic, unbroken for more than forty years, and now questioned for the first time. It would be a narrow conception of jurisprudence to confime the notion of "laws" to what is found written on the statute books, and to disregard the gloss which life has written upon it. Settled state practice cannot supplant constitutional guarantees, but it can establish what is state law. ... And if the state supreme court chooses to cover up under a formal veneer of uniformity the established system of differentiation between two classes of property, an exposure of that fiction is not enough to establish its unconstitutionality. . . . the Equal Protection Clause is not a command of candor.

\footnotetext{
${ }^{138 N a s h v i l l e, ~ C . ~ \& ~ S t . ~ L . ~ R y . ~ v . ~ B r o w n i n g, ~} 310$ U.S. 362, 369 (1940). The first clause of the sentence quoted in the text reads "[s]ince, so far as the Federal Constitution is concerned, a state can put railroad property into one pigeonhole and other property into another ..." Ibid.

${ }^{139}$ See text following note 124 supra.

140310 U.S. 362 (1940).

${ }^{141}$ Id. at 369.
} 
The Court's answer would presumably be the one it gave in Allegheny: "There is no suggestion in the opinion of the Supreme Court of West Virginia, or from any other authoritative source, that the State may have adopted a different system in practice from that specified by statute." 142 But it is difficult to reconcile this view with the West Virginia Supreme Court's declaration that "[ $t]$ he uniform use of recent deed values as the basis for appraising property subject to ad valorem taxation does not violate $W$. Va. Const., art X, $\$ 1$ ['taxation shall be equal and uniform throughout the State']." 143 If the Tennessee Suprene Court niay "cover up under a formal veneer of uniformity the established system of differentiation between two classes of property," 144 why may not the West Virginia Suprene Court do so? Perhaps the evidence of the adoption of an implicit policy apphed evenhandedly to all similarly situated property in the state was not as strong in West Virginia as it was in Tennessee. ${ }^{145}$ In any event, the Court's opinion in Allegheny leaves us with this perplexing question: When does "intentional systematic undervaluation by state officials of property in the same class," 146 which is nevertheless sanctioned by the highest court of the state as satisfying that state's uniformity and equality requirement, amount merely to a covering up "under a formal veneer of uniformity the established system of differentiation between two classes of property"? 147

There is one final variation on Allegbeny's implications for the relationship between federal and state law that is worthy of consideration, illustrated by a recent decision of the Nebraska Supreme Court. ${ }^{148}$ Most personal property in Nebraska is exempt froni taxation. The personal property of railroads, pipelines, and other centrally assessed utilities is taxable, however. After the railroads' personal property had been held excludable from ad valorem taxation under a federal statute protecting railroads from discriminatory taxation, ${ }^{149}$ the pipelines, which are not protected by the statute,

${ }^{142} 109$ S.Ct. at 638.

${ }^{143}$ In re 1975 Tax Assessments Against Oneida Coal Co., 360 S.E.2d 560, 564 (W. Va. 1987).

${ }^{144}$ Nashville, C. \& St. L. Ry., 310 U.S. at 369.

${ }^{145}$ See Allegbeny, 109 S.Ct. at 638-39.

${ }^{146}$ Sunday Lake Iron, 247 U.S. at 352-53.

${ }^{147}$ Nasbville, C. \& St. L. Ry., 310 U.S. at 369.

${ }^{148}$ Northern Natural Gas Co. v. State Board of Equalization and Assessment, 232 Neb. 806, 443 N.W.2d 249 (1989).

14949 U.S.C. $\$ 11503$ (1982). 
claimed that they were entitled to the same treatment as the railroads. Relying on both the state uniformity provision and the federal Equal Protection Clause, the Nebraska court sustained the pipelines' claim.

The significant question raised by the Nebraska decision is whether the lowering of assessed property values of soine taxpayers pursuant to federal law ${ }^{150}$ provides other taxpayers of the same class with a right to the same treatment under the Equal Protection Clause. Although a mechamical application of Allegheny could lead to that conclusion, such a conclusion is unwarranted. In Allegheny and its predecessors, ${ }^{151}$ the states were under no federal obligation to classify. The states' classification scheme, or lack thereof, therefore governed the equal protection inquiry. So long as the states' classification inet the loose "rational basis" requirement, the only judicially cognizable equal protection question was whether the state had in fact accorded equal treatment to property it had placed in a particular class.

In the Nebraska case, by contrast, federal law created a classification scheme that is binding on the states. So long as this classification scheme has a rational basis, as the federal legislation plainly does, no substantial equal protection attack can be leveled against the classification. And this is so regardless of how the states might originally have classified the property at issue apart from their obligation to conform to federal law. In short, it would misread Allegheny to conclude that the Equal Protection Clause requires that all property the state places in a particular class must be treated alike when federal law dictates that one subclass ${ }^{152}$ of such property be assessed at a lower rate than that prescribed by the state for the class in question. 153

1soThere are federal statutes providing motor carriers and air carriers with similar protection to that afforded railroads against discriminatory property taxation. 49 U.S.C. $\$ 11503$ a (1982); 49 U.S.C. App. \$1513(d) (1982).

1sisee note 130 supra.

${ }^{152}$ As indicated above, the subclassification must be able to survive equal protection scrutiny.

153See State v. Colonial Pipeline Co., 471 So. 2d 408 (Ala. Civ. App. 1984), writ. quashed, Ex Parte Colonial Pipeline Co., 471 So. $2 d 413$ (Ala. 1985), appeal dismissed, 474 U.S. 936 (1985) and Federal Express Corp. v. Tennessee State Board of Equalization, 717 S.W.2d 873 (Tenn. 1986) both of which rcached conclusions contrary to the Nebraska Supreine Court on this issue.

The only other equal protection issue addressed by the Court during its 1988 Term was raised by Amerada Hess. The Court summarily dismissed the claim, noting that "there is no discrininatory classification" underlying New Jersey's denial of the windfall profit tax deduc- 


\section{INTERGOVERNMENTAL IMMUNITY}

From the very beginning of our constitutional history, it has been clear that the states may not impose taxes discriminating against the federal government. Indeed, the seminal case articulating the doctrine of federal immunity from state taxation, McCulloch $v$. Maryland, ${ }^{154}$ involved a tax that discriminated against the federal government, and the decision could have been read as suggesting that the immunity the federal government enjoyed from state taxation applied only to taxes that discriminated against the federal government. ${ }^{155}$ In any event, despite the Court's narrowing of the federal government's immunity in cases involving nondiscrimmatory taxes, ${ }^{156}$ the Court has steadfastly adhered to the fundannental principle that the Supremacy Clause bars taxes discriminating against the federal government. ${ }^{157}$

The Court revisited the question of the federal government's immunity from discriminatory taxation during its 1988 Term in Davis $v$. Michigan Department of Treasury. ${ }^{158}$ Like many other states, Michigan exempted from personal inconie taxation all retirement benefits paid by the state or its political subdivisions while taxing retirenient benefits paid by all other eniployers, including the federal government. Paul Davis, a former federal einployee who argued the case on his own behalf in the Supreme Court, contended that Michigan's exemption for state but not federal employees was barred by federal law. Although the technical question before the Court was whether the state's disparate treatunent of state and federal employees violated a federal statute preserving federal employees' immunity from discriminatory taxation, ${ }^{159}$ the Court concluded that the immunity

tion and that "there is unquestionably a rational basis" for such denial. Amerada Hes, $109 \mathrm{~S} . \mathrm{Ct}$. at 1625 .

1544 Wheat. 316 (1819).

155Id. at 436; First Agricultural National Bank of Berkshire County v. State Tax Commission, 392 U.S. 229, 350 (1968) (Marshall, J., dissenting).

${ }^{156}$ See, e.g., Washington v. United States, 460 U.S. 536 (1983); United States v. New Mexico, 455 U.S. 720 (1982). Broadly speaking, nuodern case law has narrowed the federal government's immunity from nondiscriminatory taxes to levies whose legal incidence falls on the federal government.

${ }^{157}$ See, e.g., Memphis Bank \& Trust Co. v. Garner, 459 U.S. 392 (1983); Phillips Chemical Co. v. Dunias Independent School District, 361 U.S. 376 (1960).

158109 S.Ct. 1500 (1989).

${ }^{159}$ The statute at issue, 4 U.S.C. $\$ 111$ (1988), provides in pertinent part: "The United States consents to the taxation of pay or compensation for personal service as an officer or employee of 
guaranteed by the statute was "coextensive with the prohibition against discriminatory taxes embodied in the modern constitutional doctrine of intergovernmental immunity."160

Michigan's taxing scheme indisputably discriminated in favor of state retirees and against federal retirees. The state argued, however, that the individual federal retiree was not entitled to claim the protection of the immunity doctrine and, in any event, that the state's differential treatment of state and federal retirees was justified by meamingful distinctions between the two classes of taxpayers. In striking down the levy, the Court rejected both of these arguments.

The state's first contention-that the federal immunity doctrine did not protect the federal retiree-was premised on the notion that the immumity doctrine was desigued to protect the federal governinent, not private entities or individuals. So long as the challenged tax did not interfere with the federal government's ability to perform its governmental functions, the argument continued, there has been no violation of the immunity doctrine. While agreeing with the state's characterization of the overall purpose of the immunity doctrine, the Court disagreed with the inference the state drew from it. In the Court's eyes, it simply "does not follow that private entities or individuals who are subjected to discriminatory taxation on account of their dealings with a sovereign cannot themselves receive the protection of the constitutional doctrine."161 Indeed, the Court observed that all precedent was to the contrary, ${ }^{162}$ and the Court saw no reason to depart from that precedent.

The state's second defense of the less favorable treatment of federal as compared to state retirees was based on the ground that there were significant differences between the two classes of taxpayers. The state argued that its interest in hiring and retaining qualified civil servants through the inducement of exempting retirement benefits justified the preferential treatment of its retired employees. But the Court found this argument beside the point because it merely showed that the state had a rational basis for discriminating between

\footnotetext{
the United States . . . by a duly constituted taxing authority having jurisdiction, if the taxation does not discriminate against the officer or employee because of the source of the pay or compensation."

160109 S.Ct. at 1506.

161 lbid.

${ }^{162}$ See, e.g., cases cited in note 157 supra.
} 
two groups of retirees, not that there were significant differences between the classes. ${ }^{163}$

The state found further significant differences between state and federal retirees warranting exemption for the former but not the latter in the fact that state retirees generally received less generous retirement benefits than their federal counterparts. The Court again was unpersuaded. Even assuming the state was correct in its evaluation of the relative value of state and federal retirement benefits, the discrimination the state practiced did not serve its ostensible purpose: "A tax exemption truly intended to account for differences in retirement benefits would not discriminate on the basis of the source of those benefits, as Michigan's does; rather it would discriminate on the basis of the amount of benefits received by individual retirees."164

Justice Stevens filed a lone dissent from the Court's opinion in Davis. He recognized that there was "discrimination" against federal in favor of state retirees, but he did not regard such discrimination as unconstitutional. "The fact that a State may elect to grant a preference, or an exemption, to a small percentage of its residents does not make the tax discriminatory in any sense that is relevant to the doctrine of intergovernmental immunity." 165 In Justice Stevens' view, so long as the tax imposed on federal retirees was imposed on the vast majority of voters in the state, as Michigan's tax was, there is a sufficient "political check" against excessive taxation to obviate the concerns that underlie the intergovernmental immunity doctrine. ${ }^{166}$

As Davis suggests, the critical issue in cases involving allegations of state tax discrimination against the federal government often boils down to the delineation of the appropriate universe of taxpayers with whom the federal taxpayers are to be compared. In Davis and other cases $^{167}$ in which those who dealt with the federal government were treated like the vast majority of other taxpayers in the state, but less favorably than a small group of taxpayers who dealt with the state,

163109 S.Ct. at 1508 . The Court reiterated the point it had made in response to a similar argument in Pbillips Cbemical, 361 U.S. 376, that the criteria for adjudicating alleged discrimination against the federal government are not the loose standards associated with equal protection analysis but rather the existence of "significant differences" between the classes. Ibid.

164 Ibid.

$165 \mathrm{Id}$. at 1511 .

160Id. at 1512-13.

${ }^{167}$ See Pbillips, 361 U.S. 376(1960); Moses Lake Homes, Inc. v. Grant Co1mty, 365 U.S. 744 (1961); Memphis Bank, 459 U.S. 392 (1983); United States v. City of Manassas, 108 S. Ct. 1568 (1988) aff'g without opinion 830 F.2d 530 (4th Cir. 1987). 
the question whether there is unconstitutional discrimination depends entirely on whether one limits the comparison to those who deal with the federal and state governments or whether one takes account of the vast majority of other taxpayers who are treated like those who deal with the federal government. Despite Justice Stevens' plea that the relevant question is whether the vast majority of taxpayers in the state are treated like those who deal with the federal government, thereby providing a "political check" against abuse of the power to tax, ${ }^{168}$ the Court's precedents show its strong mclination to strike down taxes that favor those who deal with the state over those who deal with the federal government. ${ }^{169}$ However attractive Justice Stevens' position may be im theory, the Court apparently feels more comfortable with the simpler notion that "it does not seem too much to require that the State treat those who deal with the Government as well as it treats those with whom it deals itself."170

The Court has not clearly indicated, on the other hand, whether a statute that treats those who deal with public or exempt entities (imcluding the federal government) differently from those who deal with the private sector constitutes unconstitutional discrimination against the federal government. For example, would a statute imposing a gross receipts tax on public contractors be constitutional? In most cases, the issue does not arise because those who deal with the federal government are treated like all other taxpayers in the state, or like all other taxpayers except a favored class of taxpayers who deal with the state. In light of Davis and other cases condemning taxes that treat those who deal with the federal government differently from those who deal with the state, one suspects that the Court would invalidate a tax treating those who deal with the federal government differently from taxpayers in the private sector except those who deal with public entities or other exempt property owners. ${ }^{171}$

Whatever the doctrinal significance of Davis, its fiscal implications

\footnotetext{
${ }^{168}$ Davis, 109 S.Ct. at 1513, 1514; $q$. United States v. County of Fresno, 429 U.S. 452, 458 (1977).

${ }^{169}$ See note 167 supra.

170Pbillips, 361 U.S. at 385.

${ }_{171}$ See United States v. Montana, 437 F. Supp. 354 (D. Mont. 1977), rev'd on other grounds, 440 U.S. 147 (1979) (invalidating gross receipts tax limited to public contractors); Montana v. United States, 440 U.S. 147, 167-72 (White, J., dissenting); County of Fresno, 429 U.S. at 47172 (Stevens, J., dissenting) (tax limited to lessees of publicly owned property unconstitutional); but see Peter Kiewit Sons' Co. v. State Board of Equalization, 161 Mont. 140, 505 P.2d 102 (1973).
} 
for the states are truly staggering. Nearly half the states accorded disparate treatment to state and federal retirees prior to Davis. ${ }^{172} \mathrm{Re}-$ fund exposure has been estimated at $\$ 140-192$ million for Arizona, $\$ 30-40$ million for Iowa, $\$ 160$ million for Missouri, $\$ 66$ million for Oklahoma, $\$ 142$ million for Oregon, $\$ 150$ million for South Carolina, $\$ 370$ million for Virginia, and $\$ 130$ million for Wisconsin, to name just a few of these states. ${ }^{173}$ State legislatures across the country have been scrambling to deal with the problem created by Davis, either by exempting federal employees, taxing state employees, or some combination of both. ${ }^{174}$ And these legislative solutions are certain to spawn additional litigation. As Georgia's state budget director put it on the eve of a legislative session that nobody wanted which was called to adopt a pension plan that nobody likes: "I think we'll probably be sued by the state employees . . ., we'll be sued by the federal employees, and we'll be sued by the general public."175

\section{Conclusion}

During its 1988 Term, the Court harvested another bumper crop of state tax cases. The Court addressed issues ranging across the entire constitutional spectrum, ${ }^{176}$ and it rendered decisions of considerable practical significance. One might have thought that the flow of state tax litigation to the Supreme Court would have been the first casualty of the elimination of the Court's mandatory appellate

172BNA, Daily Tax Report G-1 (August 11, 1989); $c f$. Davis, 109 S.Ct. at 1511 n.3 (Stevens, J., dissenting).

173BNA, Daily Tax Report, note 172 supra, at G-2-G-3.

${ }^{174}$ Ibid.

175"Special legislative session called to patch state's pension law," Athens Daily News, p. 1, col. 2, Sept. 10, 1989.

The Court decided two other cases during its 1988 Term involving Supremacy Clause and intergovernmental immunity issues. Both were narrow in scope and of relatively modest import. In Shell Oil Co. v. Iowa Department of Revenue, 109 S. Ct. 582 (1989), the Court held that the provision of the Outer Continental Shelf Lands Act that "State taxation laws shall not apply to the outer Continental Shelf," 43 U.S.C. \$1333(a)(2) (1982), did not prohibit Iowa from including in Shell's apportionable tax base income that it derived from a unitary business conducted in part in the Outer Continental Shelf. In California State Board of Equalization v. Sierra Summit, Inc., 109 S. Ct. 2228 (1989), the Court held that California was neither preempted by federal law nor barred by the intergovernmental immunity doctrine from imposing a sales or use tax on bankruptcy liquidation sales.

${ }^{176}$ The 1988 Term cases considered in this article raised issues that are central to the Court's constitutional doctrine limiting state taxes. I leave it to others to untangle Court's state tax cases involving First Amendment and Indian immumity issues. See Texas Monthly, Inc. v. Bullock, 109 S. Ct. 890 (1989); Cotton Petroleum Corp. v. New Mexico, 109 S. Ct. 1698 (1989). 
jurisdiction. ${ }^{177}$ The Court's grant of plenary consideration to state tax cases shows no sign of abating, however. ${ }^{178}$ For those who labor in the state tax field, there remain many rows to plow.

\footnotetext{
17728 U.S.C.A. $\$ 1257$ (Supp. 1989).
}

${ }^{178} \mathrm{At}$ this writing, the Court has five state tax cases on its 1989 Term docket. In addition to the two 1988 Term cases set for reargument, see note 6 supra, the Court has agreed to review Jimmy Swaggart Ministries v. Board of Equalization, 204 Cal. App. 3d 151, 250 Cal. Rptr. 891 (1988), prob. juris. noted, 109 S.Ct. 1741 (1989); Franchise Tax Bd. v. Alcan Aluminium, 860 F.2d 688 (7th Cir. 1988), petition for cert. granted, 109 S.Ct. 1741 (1989); Missouri v. Jenkins, 855 F.2d 1295 (8th Cir. 1988), petition for cert. granted, 109 S.Ct. 1930 (1989). 
HeinOnline -- 1989 Sup. Ct. Rev. 2601989 